\title{
Electrochemical Abatement of Atrazine Solutions Using an Undivided Stirred Tank Cell with Pt or BDD Anode
}

\author{
Nelson P. Bravo-Yumi ${ }^{1,2}$, Patricio Espinoza-Montero ${ }^{3}$, Enric Brillas ${ }^{4}$, Juan M. Peralta- \\ Hernández ${ }^{1 *}$ \\ ${ }^{1}$ Departamento de Química, División de Ciencias Naturales y Exactas, Universidad de Guanajuato, Cerro \\ de la Venada s/n, Pueblito de Rocha, 36040, Guanajuato, México \\ ${ }^{2}$ Centro de Investigación y Control Ambiental, Departamento de Ingeniería Civil y Ambiental, Facultad de \\ Ingeniería Civil y Ambiental, Escuela Politécnica Nacional. P. O. Box 17-01-2759, Quito, Ecuador. \\ ${ }^{3}$ Escuela de Ciencias Químicas, Pontificia Universidad Católica del Ecuador, Avenida 12 de Octubre y \\ Roca, Apartado 17-01-2184, Quito, Ecuador. \\ ${ }^{4}$ Laboratori d'Electroquímica dels Materials i del Medi Ambient, Departament de Química Física, Facultat \\ de Química, Universitat de Barcelona, Martí i Franquès 1-11, Barcelona, Spain \\ Corresponding author: juan.peralta@ugto.mx
}

Received November $8^{\text {th }}$, 2017; Accepted January 12 $2^{\text {th }}, 2018$.

DOI: http://dx.doi.org/10.29356/jmcs.v62i2.367

\begin{abstract}
Nowadays, the increasing pollution of natural water effluents with herbicides, such as atrazine (ATZ, 2-chloro-4-ethylamino-6-isopropylamino-s-triazine), is an emerging problem that has not received the sufficient attention. This work presents a study on ATZ degradation under an electrochemical advanced oxidation process (EAOP), such as anodic oxidation (AO). The degradation of $175 \mathrm{~mL}$ of 10 and $40 \mathrm{mg} \mathrm{L}^{-1}$ ATZ solutions was studied using Pt or BDD as anode. The assays were made with a stirred tank cell, using a supporting electrolyte of $0.050 \mathrm{mM}$ of $\mathrm{Na}_{2} \mathrm{SO}_{4}$ at $\mathrm{pH} 3.0$ by applying $0.18,0.27$ and $0.37 \mathrm{~A}$ $\mathrm{cm}^{-2}$. The degradation rate increased by increasing current density, regardless of the anode employed. Greater amounts of ATZ were removed at higher organic load. The pesticide decay always obeyed a pseudo-first-order kinetics. A high degradation efficiency of $97 \%-99 \%$ was obtained by the more powerful AO-BDD process at $0.37 \mathrm{~A} \mathrm{~cm}^{-2}$. High performance liquid chromatography (HPLC) was used to follow the evolution of major oxidation products by AO-BDD, such as desethyl atrazine, desethyl desisopropyl atrazine and cyanuric acid.
\end{abstract}

Key words: Anodic oxidation; Atrazine; BDD; Pt; Water treatment.

Resumen. En la actualidad, la creciente contaminación de los efluentes de aguas naturales con herbicidas como la atrazina (ATZ, 2-cloro-4-etilamino-6-isopropilamino-s-triazina) es un problema emergente que no ha recibido atención suficiente. Este trabajo presenta un estudio sobre la degradación ATZ bajo un proceso electroquímico de oxidación avanzada (EAOP) como la oxidación anódica (AO). La degradación de soluciones de 10 y $40 \mathrm{mgL}^{-1}$ de ATZ en $175 \mathrm{~mL}$ se estudió usando Pt o BDD como ánodo. Los ensayos se realizaron con una celda de tanque agitada, usando un electrolito de soporte de $\mathrm{Na}_{2} \mathrm{SO}_{4} 0,050 \mathrm{mM}$ a $\mathrm{pH} 3,0$ aplicando 0,18, 0,27 y 0,37 $\mathrm{A} \mathrm{cm}^{-2}$. La tasa de degradación aumentó con el aumento de la densidad de corriente, independientemente del ánodo empleado. Se eliminaron cantidades mayores de ATZ a mayor carga orgánica. La descomposición del pesticida siempre obedeció a una cinética de pseudo primer orden. Se obtuvo una alta eficiencia de degradación de 97\% -99\% mediante el proceso más potente AO-BDD a $0,37 \mathrm{~A} \mathrm{~cm}^{-2}$. Se usó cromatografía líquida de alta resolución (HPLC) para seguir la evolución de los principales productos de oxidación mediante AO-BDD tal como desetil atrazina, desetil desisopropil atrazina y ácido cianúrico.

Palabras clave: oxidación anódica; atrazina; BDD; Pt; tratamiento del agua. 


\section{Introduction}

Atrazine (ATZ, 2-chloro-4-ethylamino-6-isopropylamino-1,3,5-triazine, $\mathrm{C}_{8} \mathrm{H}_{14} \mathrm{ClN}_{5}, M=215.68$ $\mathrm{g} \mathrm{mol}^{-1}$ ) is one of the best known triazine herbicides, extensively used to control the growth of broadleaf weeds in agricultural crops.[1] This herbicide is an environmental contaminant, because it is frequently detected in ground and surface water, as a result of its mobility in soil.[2] It is estimated that people who use groundwater as primary drinking water source are exposed to at least $0.2 \mu \mathrm{g} \mathrm{L}^{-1}$ of atrazine.[3] Atrazine can be found up to $21 \mu \mathrm{g} \mathrm{L}^{-1}$ in groundwater, $42 \mu \mathrm{g} \mathrm{L}-1$ in surface water and $40 \mu \mathrm{g} \mathrm{L}^{-1}$ in rainfall agricultural areas.[4] Since atrazine has been linked to several human health effects, a maximum contaminant level of $3 \mu \mathrm{g} \mathrm{L}{ }^{-1}$ was set in 1991, and it has not been changed since then.[5]

Atrazine has been banned in Europe since 2004, but it is still used around the world, including countries like the USA, China, Mexico, Argentina, Brazil and Ecuador.[6] The use of atrazine in South America has increased over time. In Ecuador, for example, this herbicide is applied to corn and sorghum crops with doses varying between 2 and $4 \mathrm{~L} \mathrm{ha}^{-1}$, throughout an area of approximately half a million Ha.[7] After atrazine application, it may undergo different fates, including runoff in surface waters or leaching through the ground. The slow biotic processes involved in atrazine biodecomposition in water and deeper soil layers exacerbate the persistence in the environment not only of atrazine itself, but also of its byproducts like hydroxyatrazine, desisopryl atrazine and desethyl atrazine.[8] Several papers have reported the detrimental implications and toxicological effects of atrazine to aquatic microorganisms,[9] amphibians,[4] and fish.[10] It also produces serious health issues, including cancer oncogenes in the reproductive apparatus and babies' health problems during gestation.[11]

For atrazine degradation, different traditional physicochemical techniques, including adsorption, filtration and biodegradation, have been tested.[12,13] Although these methods can degrade this herbicide, they generate sludge or other types of wastewater that require post-treatment. Recently, advanced oxidation processes (AOPs) have been widely used for wastewater treatment to remove different organic pollutants in synthetic or real effluents. [14] AOPs are based on the in-situ generation of free hydroxyl radicals ( $\left.{ }^{\circ} \mathrm{OH}\right)$, which can react quickly and non-selectively with organic pollutants, yielding $\mathrm{CO}_{2}, \mathrm{H}_{2} \mathrm{O}$ and inorganic ions as final products.[15]

Electrochemical AOPs (EAOPs) have received increasing attention for the elimination of persistent organic pollutants (POPs).[16] Electrochemical oxidation or anodic oxidation (AO) is the most popular EAOP for removing organic pollutants from wastewaters. It consists in the oxidation of pollutants in an electrolytic cell by direct anodic oxidation (direct electron transfer to the anode) and/or indirect reaction with electrogenerated species formed from water discharge at the anode, such as physically adsorbed "active oxygen" (physisorbed hydroxyl radical $\mathrm{M}\left({ }^{\circ} \mathrm{OH}\right)$ ) or chemisorbed "active oxygen” (oxygen in the lattice of a metal oxide (MO)) at the anode $\mathrm{M}$. The action of these oxidizing species leads to total or partial decontamination, respectively.[17] Table 1 summarizes some important researches about the atrazine degradation via electrooxidation process, in which we highlight the principal parameters that were studied by various authors, such as initial concentration of atrazine, electrodes used, efficiency degradation and current efficiency.

Comninellis [28] explained the different behavior of electrodes in AO, considering two limit cases: the so-called "active" and "non-active" anodes. $\mathrm{Pt}, \mathrm{IrO}_{2}$ and $\mathrm{RuO}_{2}$ are typical active anodes, whereas $\mathrm{PbO}_{2}$, $\mathrm{SnO}_{2}$ and BDD are considered to be non-active ones. The proposed model considers the initial reaction (1) in both kind of anodes, which corresponds to the oxidation of water molecules leading to the physisorbed $\mathrm{M}\left({ }^{\circ} \mathrm{OH}\right)$ :

$$
\mathrm{M}+\mathrm{H}_{2} \mathrm{O} \rightarrow \mathrm{M}\left({ }^{\bullet} \mathrm{OH}\right)+\mathrm{H}^{+}+e^{-}
$$

The surface of a non-active anode (like BDD) interacts so weakly with ${ }^{\circ} \mathrm{OH}$, that it allows the direct reaction of organic compounds with $\mathrm{M}\left({ }^{\circ} \mathrm{OH}\right)$ to yield fully-oxidized reaction products, such as $\mathrm{CO}_{2}$ via overall reaction (2):[28]

$$
a M\left({ }^{\bullet} \mathrm{OH}\right)+\mathrm{R} \rightarrow \mathrm{M}+\mathrm{mCO}_{2}+n \mathrm{H}_{2} \mathrm{O}+x \mathrm{H}^{+}+y e^{-}
$$

The BDD anode possesses a very low adsorption of organics in aqueous solutions. It mainly acts as an inert substrate that favors the interchange of electrons. Thus, $\operatorname{BDD}\left({ }^{\circ} \mathrm{OH}\right)$ produced from water discharge by reaction (1) is subsequently involved in the oxidation process of organics.[28-30] Furthermore, the overvoltage for $\mathrm{O}_{2}$ evolution and the rate of organic oxidation from physisorbed $\mathrm{M}\left({ }^{\circ} \mathrm{OH}\right)$ are closely related to the $\mathrm{M}-{ }^{\bullet} \mathrm{OH}$ interaction. In general, the weaker the interaction, the faster is the chemical reaction of organics with $\mathrm{M}\left({ }^{\bullet} \mathrm{OH}\right)$. Since BDD thin films are the best electrodes verifying this behavior, 
they have been proposed as the most suitable anode for AO. [29] In contrast, Pt is an active anode with a low production of reactive $\mathrm{Pt}\left({ }^{\bullet} \mathrm{OH}\right)$, because organics interact strongly with $\mathrm{Pt}$ surface and most of the above radicals are transformed into the chemisorbed PtO. [30]

This paper presents the results of degradation of ATZ solutions by AO process, aiming to know the relative oxidation power when using Pt or BDD as the anode. Comparative trials were made to study the effect of current density $(j)$ and ATZ concentration on its decay to clarify the role of generated ${ }^{\circ} \mathrm{OH}$. The evolution of major intermediates in AO-BDD was quantified by high performance liquid chromatography (HPLC).

Table 1. Electrooxidation performance in the treatment of Atrazine.

\begin{tabular}{|c|c|c|c|c|c|c|c|}
\hline $\begin{array}{l}\text { Electrodes } \\
\text { (Anode-cathode) }\end{array}$ & $\begin{array}{l}\% \\
\text { degradation }\end{array}$ & $\begin{array}{l}\text { Electrolysis } \\
\text { time } \\
\text { (min) }\end{array}$ & $\begin{array}{l}J \\
\left(\mathrm{~mA} \mathrm{~cm}^{-2}\right)\end{array}$ & $\begin{array}{l}\mathrm{C}_{0} \\
\text { of ATZ }\end{array}$ & $\begin{array}{l}\% \\
\text { MCE }\end{array}$ & $\begin{array}{l}\% \\
\text { TOC }\end{array}$ & References \\
\hline BDD-graphite & 95 & 240 & 2 & 100 ug $L^{-1}$ & - & 81.3 & 18 \\
\hline $\begin{array}{l}\mathrm{Ti} /\left(\mathrm{IrSnO}_{2}\right)-\mathrm{Pt} \\
\mathrm{Ti} /\left(\mathrm{IrRuSnO}_{2}\right)-\mathrm{Pt}\end{array}$ & 100 & 120 & 60 & $20 \mathrm{mg} \mathrm{L}^{-1}$ & - & $\begin{array}{l}35.15 \\
42.35 \\
\end{array}$ & 19 \\
\hline $\begin{array}{l}\text { BDD-stainless } \\
\text { steel }\end{array}$ & 90 & 360 & 100 & $30 \mathrm{mg} \mathrm{L}^{-1}$ & 20 & 90 & 20 \\
\hline $\mathrm{TI} /\left(\mathrm{RuO}_{2}\right)\left(\mathrm{IrO}_{2}\right)$ & 98.7 & & & & & & \\
\hline $\mathrm{TI} /\left(\mathrm{RuO}_{2}\right)\left(\mathrm{CeO}_{2}\right)$ & 82 & 120 & 20 & $10 \mathrm{mg} \mathrm{L}^{-1}$ & - & - & 21 \\
\hline $\mathrm{TI} /\left(\mathrm{RuO}_{2}\right)\left(\mathrm{SnO}_{2}\right)$ & 68 & & & & & & \\
\hline BDD-carbon filter & 97 & 480 & 40 & $10 \mathrm{mg} \mathrm{L}^{-1}$ & - & 97 & 22 \\
\hline $\begin{array}{l}\mathrm{Ti} /\left(\mathrm{IrO}_{2}\right)-\mathrm{Ti} \\
\mathrm{Ti} /\left(\mathrm{SnO}_{2}\right)-\mathrm{Ti}\end{array}$ & $\begin{array}{l}95 \\
75 \\
\end{array}$ & 60 & 30.7 & $100 \mathrm{ug} \mathrm{L^{-1 }}$ & - & - & 23 \\
\hline Pt-Pt & 97.5 & 240 & 70 & $0.05 \mathrm{mM}$ & - & 0 & 24 \\
\hline $\begin{array}{l}\mathrm{Ti} /\left(\mathrm{SnO}_{2-}\right. \\
\left.\mathrm{Sb}_{2} \mathrm{O}_{5} / \mathrm{PbO}_{5}\right)\end{array}$ & 95 & 180 & 40 & $\begin{array}{l}7 * 10^{-5} \\
\mathrm{~mol} \mathrm{~L}^{-1}\end{array}$ & - & - & 25 \\
\hline $\mathrm{Ti}-\mathrm{Ti}$ & 76 & 360 & 50 & $1810 \mathrm{COD}$ & 39 & - & 26 \\
\hline BDD-Pt & $>90$ & 300 & 13.3 & $20 \mathrm{mg} \mathrm{L}^{-1}$ & - & - & 27 \\
\hline
\end{tabular}

$\mathbf{C}_{0}=$ initial concentration

\section{Experimental}

\section{Chemicals}

Atrazine was of reagent grade supplied by Sigma-Aldrich. Desethyl atrazine, desethyl desisopropyl atrazine and cyanuric acid were of analytical grade from Aldrich, Panreac and Merck, respectively. The catalyst and background electrolyte were $\mathrm{FeSO}_{4} \cdot 7 \mathrm{H}_{2} \mathrm{O}$ and $\mathrm{Na}_{2} \mathrm{SO}_{4}$ purchased from Karal and JT. Baker, respectively. Solutions were prepared with ultrapure water from a Millipore Milli-Q system $\left(>18 \mathrm{M} \Omega \mathrm{cm}, 25^{\circ} \mathrm{C}\right.$ ). The solution $\mathrm{pH}$ was adjusted to 3.0 with analytical grade $\mathrm{H}_{2} \mathrm{SO}_{4}$ supplied by Merck. Solvents and other chemicals were either of analytical or HPLC grade purchased from JT. Baker and SigmaAldrich.

\section{Electrolytic systems and analytical procedures}

The experiments were carried out in a stirred tank cell at laboratory scale filled with solutions of $175 \mathrm{~mL}$. In all the assays, the solution was vigorously stirred with a magnetic bar at $500 \mathrm{rpm}$ in order to mix the organics and transport them towards/from the electrodes. As electrodes, a Pt plate (99.99\% purity from SEMPSA), graphite rod (from Sofacel) and BDD (thin film deposited on conductive Nb plate from Metakem ${ }^{\mathrm{TM}}$ ) were used. The geometric area of all electrodes was $3 \mathrm{~cm}^{2}$ and the interelectrode gap was of about $2.5 \mathrm{~cm}$. All the trials were made at a constant $j$ provided by a BK Precision 1627A power supply. 
Solutions with 10 or $40 \mathrm{mg} \mathrm{L}^{-1}$ of ATZ in $0.050 \mathrm{mM} \mathrm{Na}_{2} \mathrm{SO}_{4}$ were degraded at $\mathrm{pH} 3.0$ by AO-Pt and AO$\mathrm{BDD}$ at different $j$ values.

The solution $\mathrm{pH}$ was determined with a Pent $\mathrm{pH}-009(1) \mathrm{A} \mathrm{pH}$-meter. Samples withdrawn from electrolyzed solutions were microfiltered with $0.45 \mu \mathrm{m}$ PTFE filters from Whatman prior to immediate analysis. The decay in atrazine concentration was monitored by reversed-phase HPLC using an Agilent 1260 Infinity LC, fitted with an Agilent Eclipse C18 PAH (250 mm × $4.6 \mathrm{~mm}, 3 \mu \mathrm{m}$ particle size) column, and coupled with an Agilent G4212B photodiode array detector set at $\lambda=223 \mathrm{~nm}$. These analyses were performed by injecting $20 \mu \mathrm{L}$ aliquots into the LC upon elution of a 55:45 (v/v) $\mathrm{H}_{2} \mathrm{O}: \mathrm{CH}_{3} \mathrm{CN}$ mixture at 1 $\mathrm{mL} \mathrm{min}^{-1}$ as mobile phase. The chromatograms displayed a peak for atrazine at retention time $\left(t_{\mathrm{r}}\right)$ of 6.01 min. The degradation efficiency was then determined as follows: ${ }^{31,32}$

$$
\% \text { Degradation }=\frac{A T Z_{0}-A T Z_{t}}{A T Z_{0}} \times 100,
$$

where $\mathrm{ATZ}_{\mathrm{o}}$ and $\mathrm{ATZ}_{\mathrm{t}}$ are the herbicide concentration at initial time and time $t$, respectively. Triplicate runs were made for each trial of concentration decay, and average results were reported in figures with errors < $\pm 2 \%$.

For the detection of major aromatic products, the above Agilent LC system fitted with Hypersil ODS column (length $=125 \mathrm{~mm}$, internal diameter $=5 \mu \mathrm{m}$ ) was used. A mixture of 2:98 (v/v) methanol:phosphate buffer solution ( $\mathrm{pH}$ 6.94) was eluted in an isocratic mode with a constant flow of $1 \mathrm{~mL}$ $\mathrm{min}^{-1}$. The detection was done at $\left.\lambda=223 \mathrm{~nm}, 24\right]$ appearing cyanuric acid at $t_{\mathrm{r}}=1.77 \mathrm{~min}$, desethyl desisopropyl atrazine at $t_{\mathrm{r}}=2.12 \mathrm{~min}$ and desethyl atrazine at $t_{\mathrm{r}}=2.97 \mathrm{~min}$.

\section{Results and Discussion}

\section{Degradation of ATZ by anodic oxidation}

The comparative oxidation power of AO for ATZ degradation was checked with two anodic materials, namely Pt and BDD, and a graphite cathode. Solutions with 10 or $40 \mathrm{mg} \mathrm{L}^{-1}$ in $0.050 \mathrm{M} \mathrm{Na}_{2} \mathrm{SO}_{4}$ at pH 3.0 and $25^{\circ} \mathrm{C}$ were treated at $j$ values between 0.18 and $0.37 \mathrm{~A} \mathrm{~cm}^{-2}$ for $180 \mathrm{~min}$. In all cases, its $\mathrm{pH}$ dropped slightly to a final value close to 2.6-2.7; this behavior is due to the fact that atrazine can generate many acidic compounds of low molecular weight, which decreases the $\mathrm{pH}$. On the other hand, the protons that are formed in the reaction (1) are compensated by the $\mathrm{OH}^{-}$ions that are formed in the cathode, when water is reduced to $\mathrm{H}_{2}$ gas, as expected if recalcitrant short-chain carboxylic acids are generated as final byproducts.[30-345] In fact, if the solution is electrolyzed without atrazine, no change in $\mathrm{pH}$ would be observed.

Fig. 1a shows the normalized ATZ abatement for a $10 \mathrm{mg} \mathrm{L}^{-1}$ herbicide solution at different $j$ values by AO-Pt. Higher $j$ increased the degradation rate due to the concomitant acceleration of reaction (1) generating greater quantities of oxidant $\operatorname{Pt}\left({ }^{\circ} \mathrm{OH}\right)$. The exponential drop in concentration of these trials was examined as pseudo-order kinetics according to the expression:

$$
\ln \left(C_{0} / C_{t}\right)=k_{1} t \text {, }
$$

where $k_{1}$ is the apparent rate constant. Fig. $1 \mathrm{~b}$ highlights an excellent fit using Eq. (4), giving rise to increasing $k_{1}$-values of $0.0044 \mathrm{~min}^{-1}\left(R^{2}=0.991\right)$ for $0.18 \mathrm{~A} \mathrm{~cm}^{-2}, 0.0058 \mathrm{~min}^{-1}\left(R^{2}=0.991\right)$ for $0.27 \mathrm{~A} \mathrm{~cm}^{-}$ ${ }^{2}$ and $0.0060 \mathrm{~min}^{-1}\left(R^{2}=0.994\right)$ for $0.37 \mathrm{~A} \mathrm{~cm}^{-2}$. This behavior suggests the formation of a low and steady concentration of $\mathrm{Pt}\left({ }^{\circ} \mathrm{OH}\right)$ to attack the ATZ in each $j$ checked.

Fig. 1c presents the change of degradation efficiency with electrolysis time for the assays of Fig. 1a. An enhancement of this parameter can be observed with raising $j$, finally attaining values of $19 \%, 38 \%$ and $49 \%$ for $0.18,0.27$ and $0,37 \mathrm{~A} \mathrm{~cm}^{-2}$, respectively. These low results indicate on a low ability of Pt anode to remove ATZ molecule. This agrees with the expected low amounts of $\mathrm{Pt}\left({ }^{\circ} \mathrm{OH}\right)$ formed at the surface of active $\mathrm{Pt}$, which then possess a small degradation capacity. [30,35] 

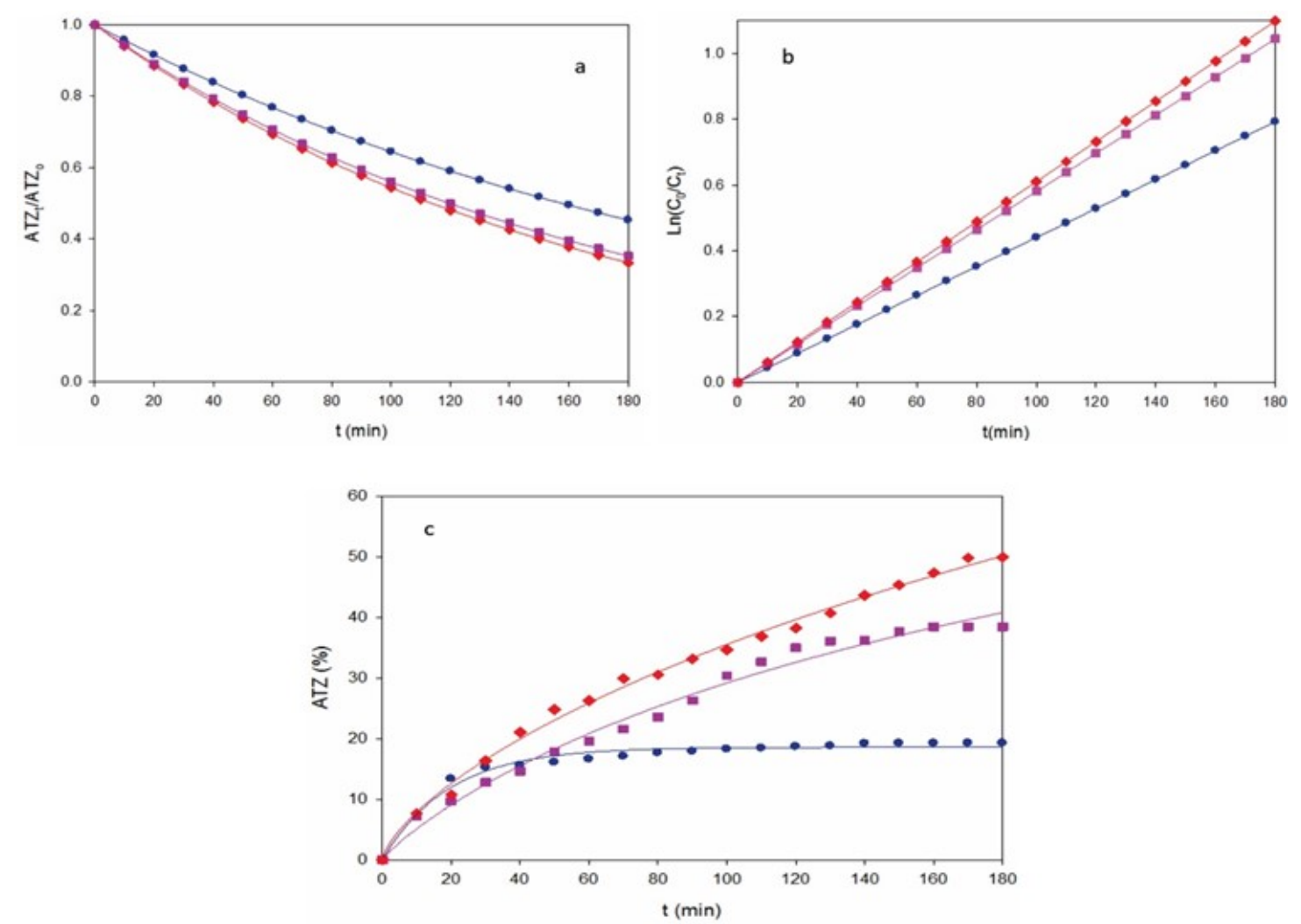

Fig. 1. (a) Normalized atrazine concentration, (b) kinetic analysis assuming a pseudo-first order reaction for ATZ and (c) degradation efficiency with electrolysis time for the AO-Pt treatment of $175 \mathrm{~mL}$ of a 10 $\mathrm{mg} \mathrm{L}^{-1} \mathrm{ATZ}$ and $0.050 \mathrm{mM} \mathrm{Na}_{2} \mathrm{SO}_{4}$ solution of $\mathrm{pH} 3.0$ and $25^{\circ} \mathrm{C}$ using a stirred tank reactor equipped with a $3 \mathrm{~cm}^{2}$ Pt anode and a $3 \mathrm{~cm}^{2}$ graphite plate cathode at current density $(j)$ : (•) $0.18 \mathrm{~A} \mathrm{~cm}^{-2},(\square) 0.27 \mathrm{~A} \mathrm{~cm}^{-}$ 2 and (») $0.37 \mathrm{~A} \mathrm{~cm}^{-2}$.

In contrast, Fig. 2a depicts a much quicker ATZ decay for the same solution by AO-BDD upon comparable conditions, with gradual upgrading of increasing $j$. This trend can be again accounted for the concomitant acceleration of reaction (1), thereby producing more reactive $\operatorname{BDD}\left({ }^{\circ} \mathrm{OH}\right)$ that destroys more rapidly the parent molecule. Fig. $2 b$ illustrates that the corresponding kinetics obeyed the pseudo-first-order reaction of Eq. (4). Increasing $k_{1}$-values of $0.0091 \mathrm{~min}^{-1}\left(R^{2}=0.998\right), 0.0121 \mathrm{~min}^{-1}\left(R^{2}=0.998\right)$ and 0.0256 $\min ^{-1}\left(R^{2}=0.998\right)$ were obtained for $0.18,0.27$ and $0.37 \mathrm{~A} \mathrm{~cm}^{-2}$, respectively. This tendency corroborates the generation of a low and steady quantity of oxidant $\operatorname{BDD}\left({ }^{\bullet} \mathrm{OH}\right)$ from reaction (1) in each trial. Furthermore, the degradation efficiency for AO-BDD was much greater than with AO-Pt, as can be inferred from the comparison of Fig. 1c with Fig. 2c. For the former method, 94\% of degradation efficiency was reached at $0.18 \mathrm{~A} \mathrm{~cm}^{-2}$, whereas it was upgraded to high values of $98-99 \%$ for 0.27 and $0.37 \mathrm{~A} \mathrm{~cm}^{-2}$. The degradation superiority of BDD can be related to its ability to generate much greater amounts of $\mathrm{BDD}\left({ }^{\circ} \mathrm{OH}\right)$ compared to those of $\mathrm{Pt}\left({ }^{\bullet} \mathrm{OH}\right)$ formed at the Pt surface. [35]

Fig. 3 and 4 shows the comparative results obtained for the degradation of $40 \mathrm{mg} \mathrm{L}^{-1}$ ATZ, using AO-Pt and AO-BDD, respectively. In all these trials, increasing concentration abatement with growing $j$ was always found, as a result of the enhancement of $\operatorname{Pt}\left({ }^{\bullet} \mathrm{OH}\right)$ and $\mathrm{BDD}\left({ }^{\bullet} \mathrm{OH}\right)$ production from the increase in rate of the corresponding reaction (1). 

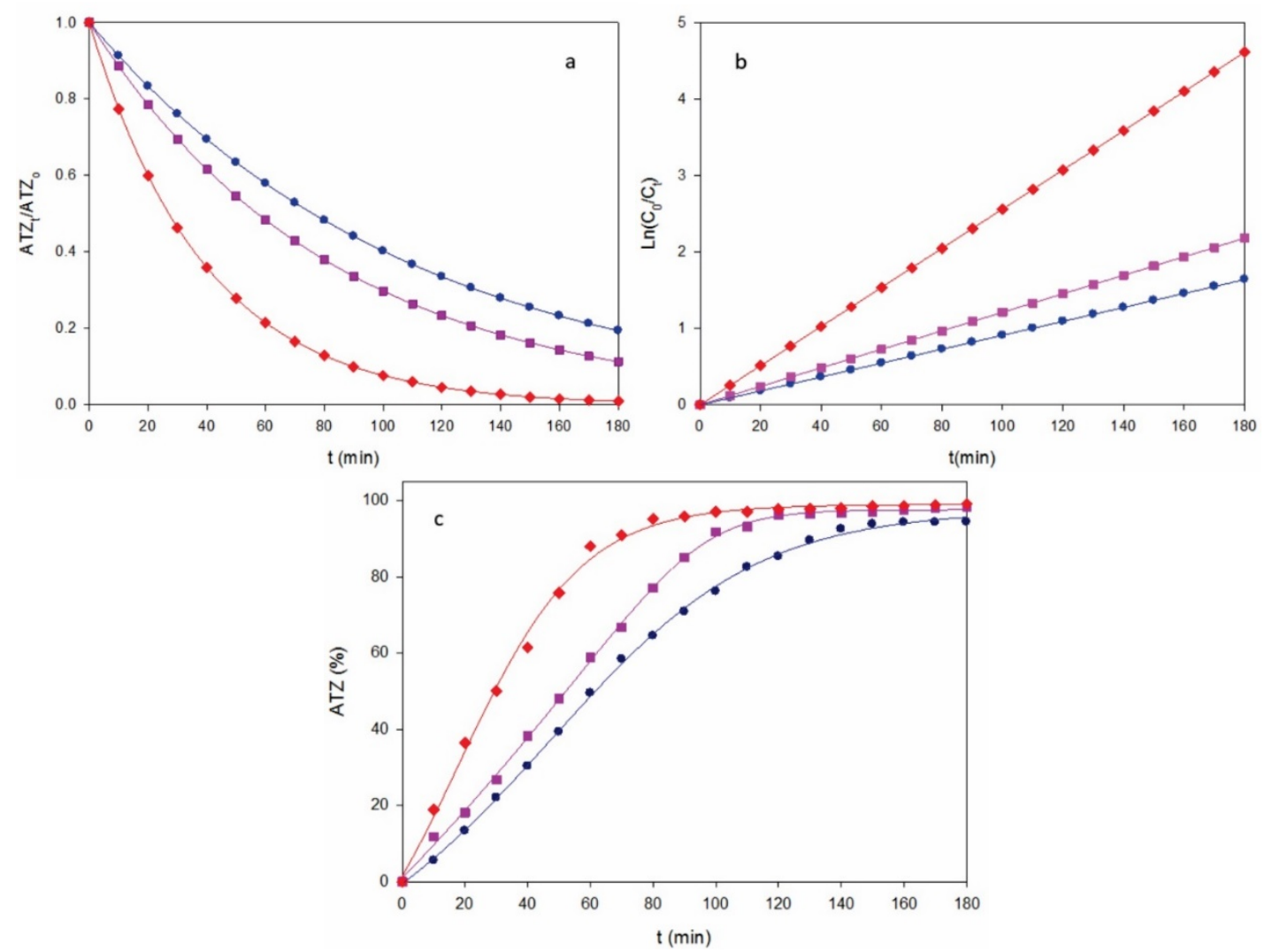

Fig. 2. (a) Normalized atrazine concentration, (b) its kinetic analysis and (c) degradation efficiency vs. electrolysis time for the AO-BDD treatment of the same solution of Fig. 1 using a $3 \mathrm{~cm}^{2} \mathrm{BDD}$ anode at $j$ : (•) $0.18 \mathrm{~A} \mathrm{~cm}^{-2},(\square) 0.27 \mathrm{~A} \mathrm{~cm}^{-2}$ and (») $0.37 \mathrm{~A} \mathrm{~cm}^{-2}$.

The good pseudo-first-order kinetics depicted in Fig. 3b allowed determining $k_{1}$-values of 0.0027 $\min ^{-1}\left(R^{2}=0.993\right)$ for $0.18 \mathrm{~A} \mathrm{~cm}^{-2}, 0.0058 \mathrm{~min}^{-1}\left(R^{2}=0.995\right)$ for $0.27 \mathrm{~A} \mathrm{~cm}^{-2}$ and $0.0075 \mathrm{~min}^{-1}\left(R^{2}=0.995\right)$ for $0.37 \mathrm{~A} \mathrm{~cm}^{-2}$. Fig. 3c evidences a rise in degradation efficiency of 39\%, 65\% and 82\% for increasing $j$ values of $0.18,0.27$ and $0.37 \mathrm{~A} \mathrm{~cm}^{-2}$. Compared to the data obtained for $10 \mathrm{mg} \mathrm{L}^{-1} \mathrm{ATZ}$, lower, equal or higher $k_{1}$-values were found at $40 \mathrm{mg} \mathrm{L}^{-1}$, but greater amounts of ATZ were removed in all cases. At $j=$ $0.37 \mathrm{~A} \mathrm{~cm}^{-2}$, for example, $32.8 \mathrm{mg} \mathrm{L}^{-1}$ of the herbicide were removed for $40 \mathrm{mg} \mathrm{L}^{-1}$, a value much higher than $4.9 \mathrm{mg} \mathrm{L}^{-1}$ determined for $10 \mathrm{mg} \mathrm{L}^{-1}$. Since the same quantity of $\mathrm{Pt}\left({ }^{\bullet} \mathrm{OH}\right)$ is formed at the same $j$, more organic events have to occur to enhance ATZ removal, when passing from 10 to $40 \mathrm{mg} \mathrm{L}^{-1}$. This is feasible by the deceleration of parasitic reactions of $\mathrm{Pt}\left({ }^{\bullet} \mathrm{OH}\right)$, since its reaction with the higher amounts of ATZ and its oxidation products are favored. These parasitic reactions involve, for example, its oxidation to $\mathrm{O}_{2}$ gas, its dimerization to $\mathrm{H}_{2} \mathrm{O}_{2}$ and its transformation into the weaker oxidant hydroperoxyl radical $\left(\mathrm{HO}_{2}{ }^{\circ}\right)$ by reactions (5) - (7): [30,34,35]

$$
\begin{aligned}
& 2 \mathrm{Pt}\left({ }^{\circ} \mathrm{OH}\right) \rightarrow 2 \mathrm{Pt}+\mathrm{O}_{2(\mathrm{~g})}+2 \mathrm{H}^{+}+2 e^{-} \\
& 2 \mathrm{Pt}\left({ }^{\circ} \mathrm{OH}\right) \rightarrow 2 \mathrm{Pt}+\mathrm{H}_{2} \mathrm{O}_{2} \\
& \mathrm{Pt}\left({ }^{\circ} \mathrm{OH}\right)+\mathrm{H}_{2} \mathrm{O}_{2} \rightarrow \mathrm{Pt}\left(\mathrm{HO}_{2}^{\circ}\right)+\mathrm{H}_{2} \mathrm{O}
\end{aligned}
$$

Similar conclusions can be inferred from the results obtained by AO-BDD. Fig. 4a illustrates the change of herbicide content for $40 \mathrm{mg} \mathrm{L}^{-1} \mathrm{ATZ}$ at the $j$ values tested, and Fig. $4 \mathrm{~b}$ shows the corresponding kinetic analysis. From this behavior, $k_{1}$-values of $0.0065 \mathrm{~min}^{-1}\left(R^{2}=0.990\right)$ for $0.18 \mathrm{~A} \mathrm{~cm}^{-2}, 0.0101 \mathrm{~min}^{-1}$ $\left(R^{2}=0.991\right)$ for $0.27 \mathrm{~A} \mathrm{~cm}^{-2}$ and $0.0174 \mathrm{~min}^{-1}\left(R^{2}=0.993\right)$ for $0.37 \mathrm{~A} \mathrm{~cm}^{-2}$, respectively, which were significantly smaller than those of $10 \mathrm{mg} \mathrm{L}^{-1}$, indicating that $k_{1}$ is not a true rate constant, since it depends on the experimental conditions used. The corresponding degradation efficiencies were $48 \%, 63 \%$ and $97 \%$ (Fig. 4c), which accounts for the removal of greater amounts of ATZ for 40 than for $10 \mathrm{mg} \mathrm{L}^{-1}$ (Fig. 2c). 
This is due to the predominant reaction of more $\operatorname{BDD}\left({ }^{\bullet} \mathrm{OH}\right)$ with higher organic load, which proceeds from the inhibition of its parasitic reactions, similar to reactions (5) - (7).
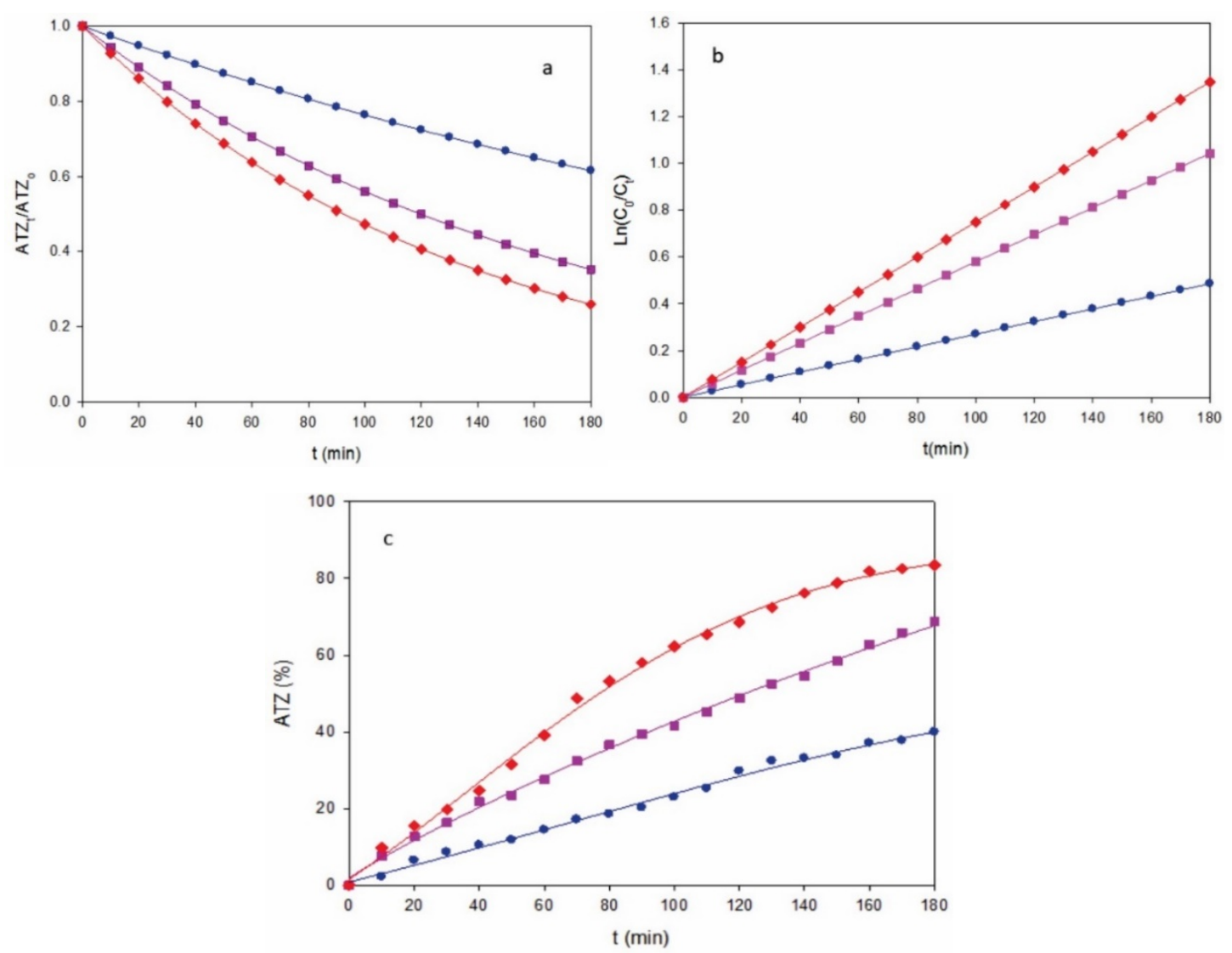

Fig. 3. Time-course of (a) normalized atrazine concentration, (b) pseudo-first-order kinetic analysis of concentration decay and (c) degradation efficiency for the AO-Pt treatment of $175 \mathrm{~mL}$ of a $40 \mathrm{mg} \mathrm{L}^{-1}$ ATZ and $0.050 \mathrm{mM} \mathrm{Na}_{2} \mathrm{SO}_{4}$ solution of $\mathrm{pH} 3.0$ and $25^{\circ} \mathrm{C}$ using a stirred Pt/graphite tank reactor at $j$ : (•) $0.18 \mathrm{~A}$ $\mathrm{cm}^{-2},(\square) 0.27 \mathrm{~A} \mathrm{~cm}^{-2}$ and $(\diamond) 0.37 \mathrm{~A} \mathrm{~cm}^{-2}$.

Regarding the works reviewed in the Table 1, it is possible to observe that several investigations, in which the atrazine electrochemical degradation has been studied, have begun with low concentrations of

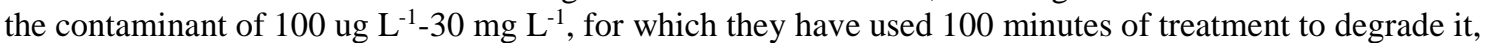
as well as high energy values; they have also tested several electrode materials. However, in our work, we report the results of atrazine degradation in high concentrations of atrazine, $40 \mathrm{mg} \mathrm{L}^{-1}$, which is its solubility limit, and it is also the concentration close to the one which is applied in real crops. Under these conditions, $97 \%$ atrazine degradation efficiency is obtained, using only $0.37 \mathrm{~A} \mathrm{~cm}^{-2}$ of energy and a BDD electrode. In addition, the aromatic products detected are in very low concentration and are not dangerous for the environment. In the light of these results, we are reporting the adequate conditions to carry out a viable treatment of this compound. 

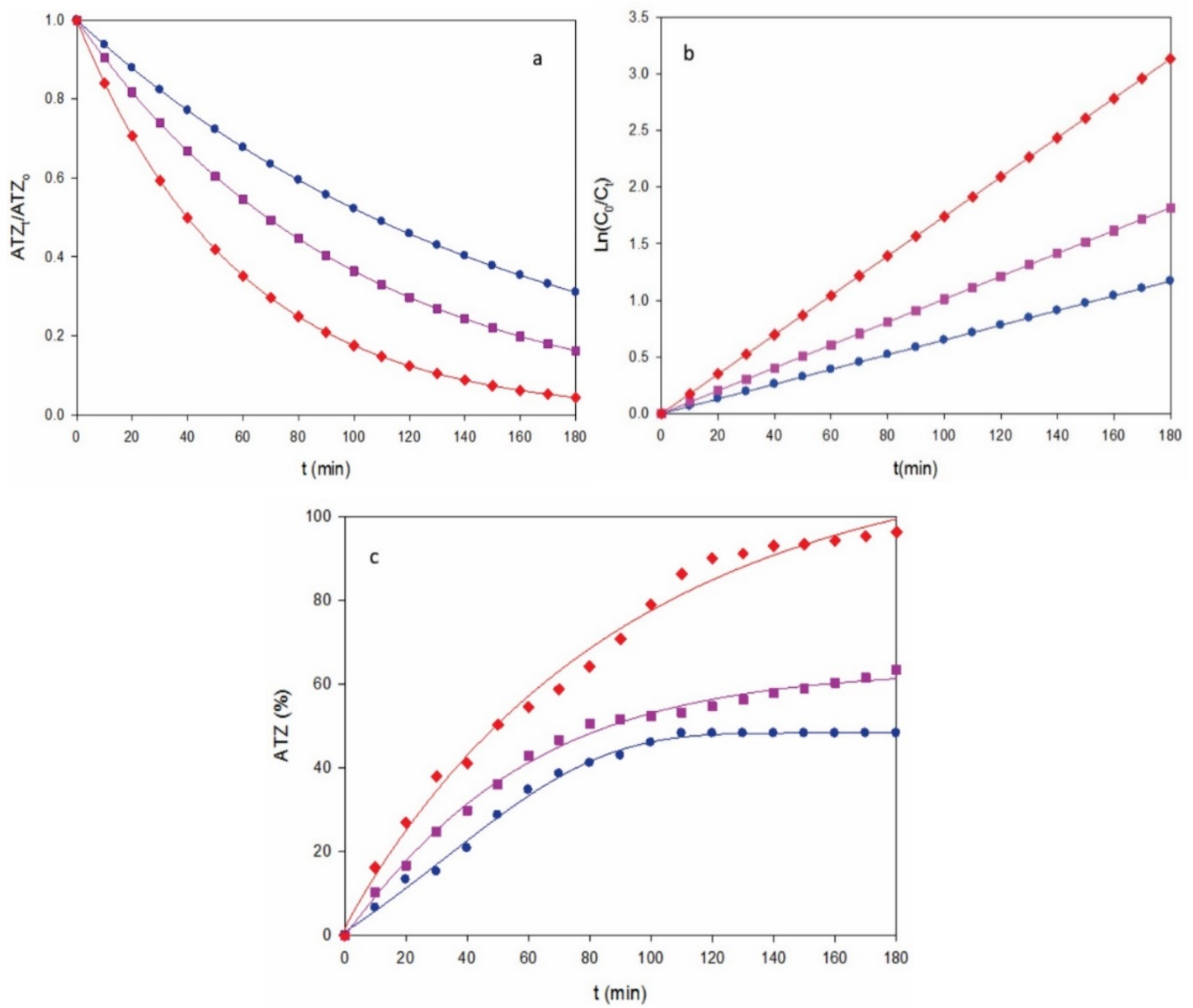

Fig. 4. Change of (a) normalized atrazine concentration, (b) analysis considering a pseudo-first order kinetics for ATZ and (c) degradation efficiency with electrolysis time for the AO-BDD treatment of the solution of Fig. 3 with a stirred BDD/graphite tank reactor at $j:(\bullet) 0.18 \mathrm{~A} \mathrm{~cm}^{-2},(\square) 0.27 \mathrm{~A} \mathrm{~cm}^{-2}$ and (») $0.37 \mathrm{~A} \mathrm{~cm}^{-2}$.

\section{Evolution of primary aromatic products}

Fig. 5a-c highlights the evolution of the concentration of major primary products, such as cyanuric acid, desethyl desisopropyl atrazine and desethyl atrazine determined by HPLC during the AO-BDD treatments of the $40 \mathrm{mg} \mathrm{L}^{-1}$ ATZ upon the conditions of Fig. 4a. These products proceed from the hydroxylation and/or dealkylation of the parent molecule upon the attack of $\operatorname{BDD}\left({ }^{\bullet} \mathrm{OH}\right)$. As can be seen, the maximum accumulation of all compounds appears between 120 and $140 \mathrm{~min}$, regardless of the applied $j$, meaning that at such time a significant amount of generated $\operatorname{BDD}\left({ }^{\circ} \mathrm{OH}\right)$ began already to attack the primary products formed. Desethyl atrazine was the product more easily formed, with a maximum of about $80 \mu \mathrm{g} \mathrm{L}^{-1}$ at $0.37 \mathrm{~A} \mathrm{~cm}^{-2}$, a value that progressively decreased to about 40 and $12 \mu \mathrm{g} \mathrm{L}^{-1}$ for 0.27 and 0.18 $\mathrm{A} \mathrm{cm}^{-2}$, respectively (Fig. 5b). This suggests a much larger reactivity of atrazine with the higher amounts of $\mathrm{BDD}\left({ }^{\bullet} \mathrm{OH}\right)$ formed as increasing $j$ to yield desethyl atrazine. A higher rise in cyanuric acid concentration can also be observed in Fig. 5a from 0.18 to $0.27 \mathrm{~A} \mathrm{~cm}^{-2}$ by the larger $\operatorname{BDD}\left({ }^{\circ} \mathrm{OH}\right)$ productivity, which is inhibited by increasing $j$ up to $0.37 \mathrm{~A} \mathrm{~cm}^{-2}$. This trend was much less relevant for desethyl desisopropyl atrazine, since it presented its maximal value between about $8 \mu \mathrm{g} \mathrm{L}^{-1}$ at $0.18 \mathrm{~A} \mathrm{~cm}^{-2}$ and near $10 \mu \mathrm{g} \mathrm{L}^{-1}$ at $0.37 \mathrm{~A} \mathrm{~cm}^{-2}$ (Fig. $5 \mathrm{c}$ ). These results point to the raising initial generation of products in the order: desethyl desisopropyl atrazine < cyanuric acid < desethyl atrazine [18]. 

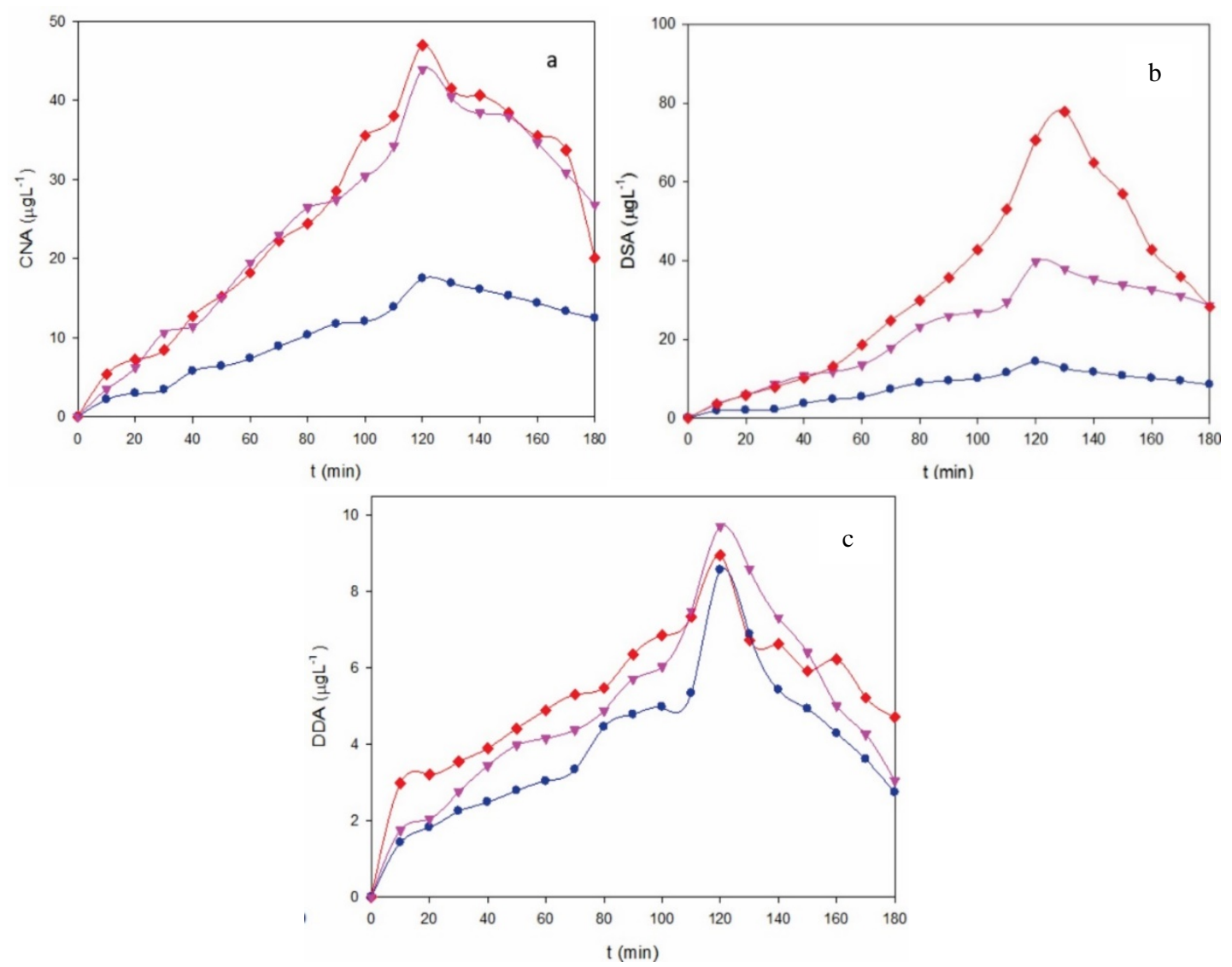

Fig. 5. Time course of the concentration of (a) cyanuric acid, (b) desethyl desisopropyl atrazine and (c) desethyl atrazine during the AO-BDD treatment of Fig. 4 at $j:(\bullet) 0.18 \mathrm{~A} \mathrm{~cm}^{-2},(\boldsymbol{\nabla}) 0.27 \mathrm{~A} \mathrm{~cm}^{-2}$ and $(\bullet)$ $0.37 \mathrm{~A} \mathrm{~cm}^{-2}$.

\section{Conclusions}

It has been shown that ATZ in acidic sulfate solution is more rapidly degraded by AO using a nonactive BDD anode than an active Pt one. This is due to the higher production of oxidant $\mathrm{BDD}\left({ }^{\circ} \mathrm{OH}\right)$ at the former anode. The ATZ decay always obeyed a pseudo-first-order kinetics. Increasing $j$ always accelerated the degradation process by the greater rate of generated hydroxyl radicals, giving rise to the growth of $k_{1}$. The rise in ATZ concentration favored its removal due to the concomitant inhibition of parasitic reactions of hydroxyl radicals. The major oxidation products were more largely formed in the sequence: desethyl desisopropyl atrazine $<$ cyanuric acid $<$ desethyl atrazine.

\section{Acknowledgements}

Financial support from Universidad de Guanajuato, projects 007/2015 (Convocatoria Institucional para fortalecer la Excelencia Académica 2015) and 778/2016 (Apoyo a la Investigación Científica 20162017), is acknowledged.

\section{References}

1. Su, Y. H.; Zhu, Y. G. Environ. Pollut. 2006, 139, 32-39.

2. Barr, D. B.; Panuwet, P.; Nguyen, J. V.; Udunka, S.; Needham, L. L. Environ. Health Perspect. 2007, 115, 1474-1478.

3. Abarikwu, S. O.; Pant, A. B.; Farombi, E. O. Toxicol. In Vitro 2013, 27, 700-707. 
4. Hayes, T. B.; Collins, A.; Lee, M.; Mendoza, M.; Noriega, N.; Stuart, A. A.; Vonk, A. Proc. Natl. Acad. Sci. 2002, 99, 5476-5480.

5. $\quad$ Pappas, E. A.; Huang, C. Environ. Sci. Technol. 2008, 42, 7064-7068.

6. Mendaš, G. Arh. Hig. Rada Toksikol. 2011, 62, 191-203.

7. Jiménez, M.; Oller, I.; Maldonado, M. I.; Malato, S.; Hernández-Ramírez, A.; Zapata, A.; PeraltaHernández, J. M. Catal. Today 2011, 161, 214-220.

8. Winkelmann, D. A.; Klaine, S. J. Environ. Toxicol. Chem. 1991, 10, 335-345.

9. Graymore, M.; Stagnitti, F.; Allinson, G. Environ. Int. 2001, 26, 483-495.

10. Fan, W. Q.; Yanase, T.; Morinaga, H.; Gondo, S.; Okabe, T.; Nomura, M.; Komatsu, T.; Morohashi, K. I.; Hayes, T. B.; Takayanagi, R.; Nawata, H. Environ. Health Perspect. 2007, 115, 720-727.

11. Winchester, P. D.; Huskins, J.; Ying, J. Acta Paediatr. Int. J. Paediatr. 2009, 98, 664-669.

12. Monard, C.; Vandenkoornhuyse, P.; Le Bot, B.; Binet, F. ISME J. 2011, 5, 1048-1056.

13. Wang, X.; Guo, X.; Yang, Y.; Tao, S.; Xing, B. Environ. Sci. Technol. 2011, 45, 2124-2130.

14. Klamerth, N.; Malato, S.; Agüera, A.; Fernández-Alba, A.; Mailhot, G. Environ. Sci. Technol. 2012, 46, 2885-2892.

15. Brillas, E.; Sirés, I.; Oturan, M. A. Chem. Rev. 2009, 109, 6570-6631.

16. Sirés, I.; Brillas, E.; Oturan, M. A.; Rodrigo, M. A.; Panizza, M. Environ. Sci. Pollut. Res. 2014, 21, 8336-8367.

17. Nasr, B.; Abdellatif, G.; Cañizares, P.; Sáez, C.; Lobato, J.; Rodrigo, M. A. Environ. Sci. Technol. 2005, 39, 7234-7239.

18. Komtchou, S.; Dirany, A.; Drogui, P.; Robert, D.; Lafrance, P. Water Res. 2017, 125, 91-103.

19. Malpass, G. R. P.; Miwa, D. W.; Machado, S. A. S.; Olivi, P.; Motheo, A. J. J. Hazard. Mat. 2006, 137, 565-572.

20. Borràs, N.: Oliver, R.; Arias, C.; Brillas, E. J. Phy. Chem. A. 2010, 114, 6613-6621.

21. Santos, T. É. S.; Silva, R. S.; Eguiluz, K. I. B.; Salazar-Banda, G. R. Mat. Letters. 2015, 146, 4-8.

22. Oturan, N.; Brillas, E.; Oturan, M. Environ. Chem. Letters. 2012, 10, 165-170.

23. Zaviska, F.; Drogui, P.; Blais, J.-F.; Mercier, G.; Lafrance, P. J. Hazard. Mat. 2011, 185, 1499-1507.

24. Mamián, M.; Torres, W.; Larmat, F. E. Portugaliae Electrochim. Acta. 2009, 27, 371-379.

25. Xue, B.; Wang, B.; Wang, J.-Y.; Sun, J. 4th International Conference on Bioinformatics and Biomedical Engineering, iCBBE, 2010.

26. Kamal Mohamed, D. S. M.; Perumal, V. (2011). Sust. Environ. Res. 2011. 2, 401-406.

27. Garza-Campos, B. R.; Guzmán-Mar, J. L.; Reyes, L. H.; Brillas, E.; Hernández-Ramírez, A.; RuizRuiz, E. J. Chemosphere. 2014. 97, 26-33.

28. Comninellis, C. Electrochim. Acta 1994, 39, 1857-1862.

29. Marselli, B.; Garcia-Gomez, J.; Michaud, P.-A.; Rodrigo, M. A.; Comninellis, C. J. Electrochem. Soc. 2003, 150, D79.

30. Martínez-Huitle, C. A.; Brillas, E. Appl. Catal. B Environ. 2009, 87, 105-145.

31. Bedolla-Guzman, A.; Sirés, I.; Thiam, A.; Peralta-Hernández, J. M.; Gutiérrez-Granados, S.; Brillas, E. Electrochim. Acta. 2016, 206, 307-316.

32. Garcia-Segura, S.; Brillas, E. Journal of Photochemistry and Photobiology C: Photochemistry Reviews. 2017, 1-35.

33. Borràs, N.; Oliver, R.; Arias, C.; Brillas, E. J. Phys. Chem. A. 2010, 114, 6613-6621.

34. Brillas, E.; Martínez-Huitle, C. A. Applied Catalysis B: Environmental. 2015, 603-643.

35. Flox, C.; Garrido, J. A.; Rodríguez, R. M.; Centellas, F.; Cabot, P. L.; Arias, C.; Brillas, E. Electrochim. Acta 2005, 50, 3685-3692. 